Original Article

\title{
EVALUATION OF ANTIEPILEPTIC ACTIVITY OF ETHANOLIC EXTRACT OF AZIMA TETRACANTHA ROOT IN MICE
}

\author{
MADHAVI EERIKE1 ${ }^{*}$, VENU GOPALA RAO KONDA¹, RUCKMANI ARUNACHALAM1, UMAR DAWOOD² \\ ${ }^{1}$ Dept of Pharmacology, Chettinad Hospital and Research Institute Kelambakkam, Kanchipuram (dt), Tamil Nadu 603103, India, ${ }^{2}$ Dept of \\ Pharmacology, Ragas Dental College, East Coast Road, Uthandi, Chennai 600096, Tamilnadu, India \\ Email: dr.madhavieerike@gmail.com
}

Received: 31 Jul 2016, Revised and Accepted: 20 Sep 2016

\begin{abstract}
Objective: To evaluate the antiepileptic activity of ethanolic extract of Azima tetracantha root (EEATR) against Maximal electroshock (MES) and Pentylenetetrazole (PTZ) induced seizures in mice.

Methods: 48 adult male mice were used and 4 groups with six in each were allocated to each model. 4 Groups are divided into control, standard and two test groups. The control group received normal saline, standard group, Sodium valproate $-200 \mathrm{mg} / \mathrm{kg}$ and the two test groups received an ethanolic extract of roots of Azima tetracantha (EEATR) 250 and $500 \mathrm{mg} / \mathrm{kg}$ respectively. Antiepileptic activity was assessed based on hind limb tonic extension duration, the onset of convulsions and mortality. The results were compared with control and standard.
\end{abstract}

Results: In MES model EEATR reduced the duration of hind limb extension (HLE) and seizure protection was $50 \%$ and $66.6 \%$ with 250 and 500 $\mathrm{mg} / \mathrm{kg}$ respectively. In PTZ model both the doses of EEATR delayed the onset of clonic phase and prevented death in $50 \%$ of animals in the group treated with $500 \mathrm{mg} / \mathrm{kg}$ EEATR, similar to sodium valproate. Results were analysed by ANOVA with $\mathrm{p}<0.05$ considered as significant.

Conclusion: EEATR has shown anticonvulsant activity in both MES and PTZ models. $500 \mathrm{mg} / \mathrm{kg}$ of EEATR has better protection than $250 \mathrm{mg} / \mathrm{kg}$ against seizure in MES model and equally efficacious as sodium valproate standard in PTZ model.

Keywords: Antiepileptic activity, Maximal Electroshock (MES), Pentylenetetrazole (PTZ), Azima tetracantha root, Sodium Valproate

(c) 2016 The Authors. Published by Innovare Academic Sciences Pvt Ltd. This is an open access article under the CC BY license (http://creativecommons.org/licenses/by/4.0/) DOI: http://dx.doi.org/10.22159/ijcpr.2016v8i4.15385

\section{INTRODUCTION}

Epilepsy, a disorder of brain function which is defined clinically as a syndrome of two or more unprovoked or recurrent seizures on more than one occasion [1].

Epilepsy accounts for $0.5 \%$ of global health burden. Approximately $80 \%$ of incidence is reported from developing countries [2]. It is accounted that one out of 21 men and one out of 28 women will develop epilepsy during their lifetime [3]. The incidence is high in the pediatrics age group, decreasing through adulthood until approximately $60 \mathrm{y}$ and the incidence again increases [4].

The unpredictable nature of epilepsy causes psychological stress to the individual even if the disease is well controlled. People with epilepsy may have poor health, suffer from unemployment, inability to work and higher mortality compares to non-epileptics [5]. It has been reported that there is a higher risk of suicide in epileptic individuals [6]. A low socioeconomic status has been shown to be a risk factor for developing epilepsy $[7,8]$.

Currently, the treatment of epilepsy is by pharmacological agents such as phenytoin, sodium valproate, carbamazepine, which control the excess abnormal electrical activity of brain neurones. These agents act by blocking sodium/calcium channels and balancing the inhibitory and excitatory neurotransmitter system in central nervous system. Research is going on identifying new targets and new molecules. The limitation of the use of available drugs is that they can only offer remission but not cure of epilepsy. In addition, the long term side effects and cost of especially recently introduced drugs such as levetiracetam and compliance to lifelong therapy imposes the necessity to develop new drugs.

None of the antiepileptic drugs, including those that act on newly identified targets, can be considered as an ideal drug that reliably cures epilepsy [9].

Temkin NR, reviewed many clinical trials on epilepsy and found that the use of antiepileptic drugs suppressed seizures in the short-term, but not long-term [10].
The outcome of antiepileptic treatment is also not the same in all individuals which could be due to genetic variation which has led to personalised therapy [11]

Hence in this scenario, there is a need to search for alternative drugs with lesser adverse effects and equal efficacy.

Limitations with the currently existing drugs made the researchers search for an alternative therapy from natural resources. A review on the plants having antiepileptic activity was done by Saba Hasan et $a l$., Malvi Reetesh $\mathrm{K}$ et al. and Lucindo J et al. Many Plants were evaluated for antiepileptic activity. Some of them are Allium sativum, Artemesia spp,Cissus sicyoides, Ocimum sanctum, Brahmi grihta, Dorstenia arifolia,Withania somnifera, Citrus sinensis, Datura stramonium, Terminalia glaucescens, Caesalpinia crista, Mentha cardifolia, Tetrapleura tetraptera, Ricinus communis, Taxus wallichiana, Senna singuena, Jatropha gossypiifolia, Glycerrhiza glabra, Catharanthus roseus, Passion flower etc [12-14]

Azima tetracantha Lam. (AT) is a herb used in Indian traditional medicine. Azima tetracantha is commonly called needle brush in English, mulluchangu in Ayurvedha and Kundali in sidha. It belongs to salvadoraceae family. Azima tetracantha has been traditionally used for many diseases especially root part. In Zimbabwe, root paste has been used for Snake bites, Stem juice for a headache, fever, chronic dysentery in South Africa, root and Stem juice for Rheumatism and sprain and leaf juice for a toothache, chronic diarrhea, acidity, venereal diseases, cough and cold in India andSouth Africa. Root decoction has been used Stomach disorders (diarrhea, dysentery) in Kenya, India [15].

Pharmacological actions reported for AT are anti-inflammatory, analgesic, antipyretic, antimicrobial, antifungal, antiulcer, diuretic, anticancer, anti-snake venom, and hepatoprotective and antioxidant activities [16-18]. The nephroprotective effect in acute renal failure has been recently reported [19].

Phytochemical composition

It contains alkaloids, flavonoids, glycosides, terpenoids and fatty acids. Dimeric piperidine alkaloids are azimine, azcarpaine and 
carpaine present in the whole plant. Glucosinolates and glucosinolatederived compounds present in root and fruit are 3indolylmethylglucosinolate $\mathrm{N}$-hydroxyl-3-indolylmethyl-glucosinolate $\mathrm{N}$-methoxy-3-indolylmethyl-glucosinolate and neo-ascorbigen. Flavonoids, quercetin, myricetin, rutin, are present in root and stem. Leaf contains an important terpenoids are freidelin and betasitosterols [20-22].

Considering the presence of phytochemicals such as alkaloids, flavonoids and terpenoids which are reported to have antiepileptic activity AT has been chosen in this study for evaluation of its antiepileptic activity in animal models. The root part was chosen for this study because it is traditionally more commonly used part and also it contains all basic nutrients and phytochemicals. There is no study reported for azima tetracantha for its action in central nervous system disorders.

\section{MATERIALS AND METHODS}

The study was initiated after getting approval from Institutional Animal Ethics Committee. Letter No. IAEC2/Desp. No.50/Dt. 29.07.2013.

\section{Animals}

The study was initiated after getting Institutional animal ethical committee approval. A total of 48 healthy male Swiss albino mice weighing between 25-30 grams were used for this study. Animals were obtained from the Central Animal House of CHRI. The animals were divided into 8 groups with six in each. 4 groups were allocated for each experiment. Each group was housed in clean polypropylene cage and maintained in the proper environment. All these animals had free access to food and water. The animals were acclimatized for these conditions for one week.

\section{Drugs and chemicals used in the experiment}

PTZ was purchased from Sigma Chemicals and Sodium valproate of Sanofi Synthelabo (India) was purchased from the pharmacy of Chettinad Hospital and Research Institute.

\section{Preparation of ethanolic extract of azima tetracantha roots (EEATR)}

Azima pyracantha roots were purchased from RN Rajan and Co, exporters of Herbal raw products, Chennai. Roots were milled into a coarse powder and this powder was subjected to continuous extraction with $95 \% \mathrm{v} / \mathrm{v}$ ethanol in Soxhlet apparatus for 15 cycles. The extract was then dried in a flash evaporator. $55.03 \mathrm{~g}$ of green coloured, thick and sticky residue was obtained. It was reconstituted in distilled water so that concentration obtained was $1 \mathrm{gm} / \mathrm{ml}$.

\section{Acute toxicity study}

Acute toxicity study was conducted as per OECD-423 guidelines. A total of 12 female mice divided into 4 groups with 3 in each were used for this study. ATR extract at doses 5, 50, 300 and $2000 \mathrm{mg} / \mathrm{kg}$ of was given orally in overnight fasted animals. All these animals were observed for their general behaviour, mortality and convulsions for the first $2 \mathrm{~h}$ and then hourly for the next $6 \mathrm{~h}$ and after 24,48 , and $72 \mathrm{~h}$.

The extract was found to be safe as there is no change in behaviour or mortality was observed up to the dose of $2000 \mathrm{mg} / \mathrm{kg}$. Doses, 250 and $500 \mathrm{mg} / \mathrm{kg}$ of the ethanolic extract were selected for this study based on acute toxicity test.

\section{Route of administration}

All the drugs were given through intraperitoneal route

\section{Methodology}

All the drugs required were freshly prepared before starting the experiment. The test group received the drugs calculated according to the body weight and the control group received the same volume of vehicle (distilled water) through intraperitoneal route. No food or water was given during the experiment.

\section{Experimental design}

Four groups of 24 mice with six in each were allocated to each model used Groups in each model
Group 1: Control group received distilled water, $2 \mathrm{ml} / \mathrm{kg}$, i. p.

Group 2: Standard group received Sodium valproate, $200 \mathrm{mg} / \mathrm{kg}$, i. p. Group 3: Received test drug (Test group I) $250 \mathrm{mg} / \mathrm{kg}$ of EEATR, i. p Group 4: Received Test drug (Test group II) $500 \mathrm{mg} / \mathrm{kg}$ of EEATR, i. $\mathrm{p}$

\section{Maximal electroshock (MES)-induced seizures test}

The effect of the Azima tetracantha on generalised seizures was evaluated by the maximal electroshock (MES) method as described by Schmutz M et al. [23]. Four groups of six animals in each group were selected for this model. The control (distilled water- $2 \mathrm{ml} / \mathrm{kg}$ ), standard (sodium valproate $-200 \mathrm{mg} / \mathrm{kg}$ ) and test drugs Iand II (Azima tetracantha 250 and $500 \mathrm{mg} / \mathrm{kg}$ ) were administered intraperitoneally before inducing seizures. Generalised seizures were induced half an hour later with electroshock through a pair of ear electrodes which delivered an alternating current of constant frequency $(60 \mathrm{~Hz})$ and $50 \mathrm{~mA}$ for $0.2 \mathrm{sec}$. The control group had a convulsive pattern having a tonic flexor phase, a tonic extensor phase with characteristic hind limb extension followed by clonic phase. An animal was considered to be protected if the characteristic seizure pattern is absent or there is a reduction in the duration of hind limb extension. The duration of hind limb extension, number and percentage of animals protected in each group was determined.

\section{Pentylenetetrazole (PTZ)-induced seizures test}

PTZ was used to induce seizures according to the method described by Swinyard EA et al. [24]. The mice were divided into four groups of 6 animals each. The control (distilled water- $2 \mathrm{ml} / \mathrm{kg}$ ), standard (sodium valproate- $200 \mathrm{mg} / \mathrm{kg}$ ) and test drugs IandII (Azima tetracantha 250 and $500 \mathrm{mg} / \mathrm{kg}$ ) were administered intraperitoneally half an hour before induction of convulsions. Typical convulsions began in control group with jerking movements of the body followed by clonic convulsions within 2-3 min. The treated groups were compared with that of control for the delay or latency of onset convulsions as well as protection from death which were considered as indicators of anticonvulsant activity.

\section{Statistical analysis}

Statistical analysis was done using one-way ANOVA. P valve of $<0.05$ was considered significant

\section{RESULTS}

\section{MES model}

All the animals in control group treated with electric shock developed convulsions. The standard drug sodium valproate (200 $\mathrm{mg} / \mathrm{kg}$ ) protected $83.3 \%$ (5 out of 6 ) of animals from seizures.

In group III, treated with $250 \mathrm{mg} / \mathrm{kg}$ of EEATR, 3 out of 6 animals did not develop convulsion and the percentage of protection was $50 \%$. In group IV, treated with $500 \mathrm{mg} / \mathrm{kg}$ of EEATR 4 out of 6 (66.6\%) animals did not develop seizures and in the remaining 2 animals, there was a decrease in the duration of hind limb tonic extension. In this model EEATR has significantly decreased the duration of hindlimb extension in both $250 \mathrm{mg} / \mathrm{kg}(\mathrm{P}<0.01)$, and 500 $\mathrm{mg} / \mathrm{kg} \quad(\mathrm{p}<0.001)$. The effect of test drug at $500 \mathrm{mg} / \mathrm{kg}$ was comparable to the effect of the standard drug (fig. 1 table 1).

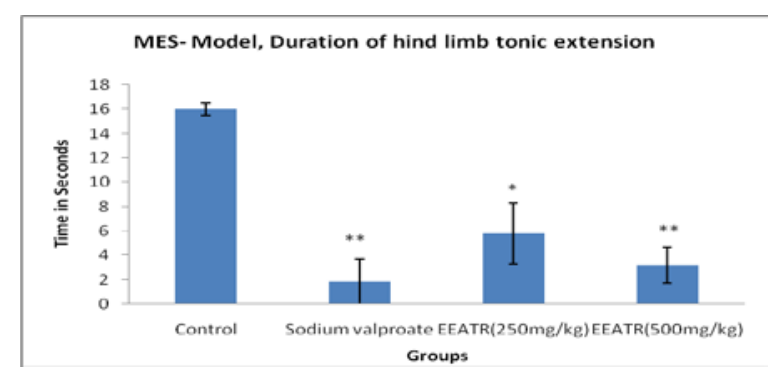

Fig. 1: Effect of EEATR on duration of hind limb extension in MES model, $N=6$, Values were expressed as MEAN $\pm S E M * p<0.01$, ${ }^{* *} \mathbf{p}<0.001$ 
Table 1: Percentage of seizure inhibition in MES model

\begin{tabular}{llll}
\hline Group (n=6) & \multicolumn{2}{l}{ Hind limb tonic extension (HTLE) } & Protection against seizure (\%) \\
\cline { 2 - 3 } & Present (+) & Absent (-) & 0 \\
\hline G-1(Control) & 6 & 0 & 83.3 \\
G-2(Standard) & 1 & 5 & 50 \\
G-3(Test drug I) & 3 & 3 & 66.6 \\
G-4(Test drug II) & 2 & 4 & \\
\hline
\end{tabular}

Table 2: Percentage of animals protected from death in PTZ model

\begin{tabular}{llll}
\hline Group (n=6) & No of animals & Percentage of animals protected from death (\%) \\
\cline { 2 - 3 } & Dead (+) & Alive (-) & \\
\hline G-1(Control) & 6 & 0 & 0 \\
G-2(Standard) & 3 & 3 & 50 \\
G-3(Test drug I) & 4 & 2 & 33.3 \\
G-4(Test drug II) & 3 & 3 & 50 \\
\hline
\end{tabular}

\section{PTZ model}

Convulsions were induced in all the animals by giving PTZ in the dose of $80 \mathrm{mg} / \mathrm{kg}$. $100 \%$ mortality was observed in control group. Sodium valproate and EEATR $(500 \mathrm{mg} / \mathrm{kg})$ significantly $(\mathrm{p}<0.05)$ increased the threshold for the onset of convulsions and had imparted 50\% protection. In the group treated with EEATR (250 $\mathrm{mg} / \mathrm{kg}) 4$ out of 6 animals died.

Thus in PTZ model the EEATR $500 \mathrm{mg} / \mathrm{kg}$ effectively increased the seizure onset time and found to have $50 \%$ protection from death similar to Sodium valproate (fig 2 and table 2 ).

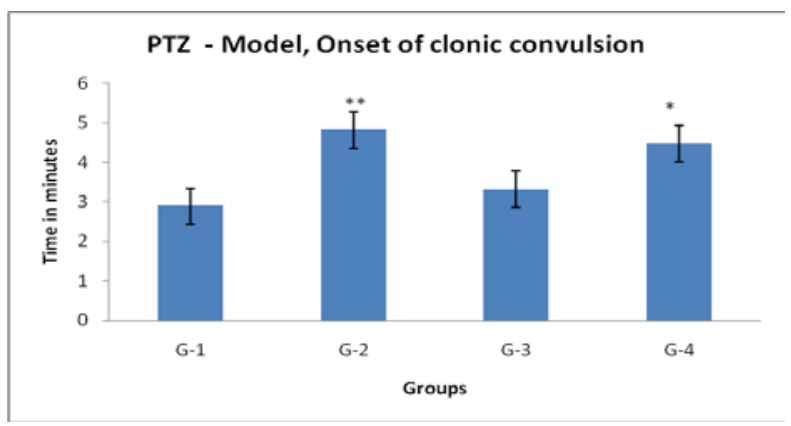

Fig. 2: Effect of EEATR on onset of convulsions in PTZ model, $\mathrm{N}=6$, Values were expressed as MEAN \pm SEM ${ }^{*} \mathrm{p}<0.05,{ }^{* *} \mathrm{p}<0.01$

\section{DISCUSSION}

The present study has evaluated the antiepileptic activity of EEATR in both MES and PTZ mice models.

The antiepileptic activity was measured by duration of hind limb extension in MES model and onset of convulsions and prevention of death in PTZ model. The MES model is the most frequently used as an animal model for identification of anticonvulsant activity of drugs for the generalised tonic-clonic seizures (GTCS). In this model, animals are stimulated with a same supramaximal current strength which induces seizures [25]. The mechanism reported for convulsions induced by MES is antagonism of GABA activity.

In our study, the percentage of seizure prevention was $83.3 \%$ in sodium valproate-treated group whereas it was $50 \%(\mathrm{P}<0.01)$ and $66.6 \%(\mathrm{p}<0.001)$ in groups treated with EEATR 250 and $500 \mathrm{mg} / \mathrm{kg}$ respectively.

PTZ induces seizures by antagonizing the inhibitory GABAergic neurotransmission and calcium channel blockade. and also increasing the excitatory neurotransmitters level causing neuronal excite toxicity leading to seizure development. This model is commonly used for screening of drugs for petit mal/absence seizures. In our study Sodium valproate and EEATR (500 mg/kg) significantly $(\mathrm{p}<0.05)$ increased the threshold for convulsions and had shown to protect $50 \%$ of the animals from death and $33.3 \%$ in the group treated with EEATR $250 \mathrm{mg} / \mathrm{kg}$.

In both the models, EEATR showed antiepileptic activity. The extent of antiepileptic activity varied between MES and PTZ models. The antiepileptic activity of EEATR was found to be lower than sodium valproate in MES model whereas it was found to be equal in PTZ model. Between the two doses of EEATR, $500 \mathrm{mg} / \mathrm{kg}$ offered higher protection in MES model. In PTZ model, there was no difference between EEATR $500 \mathrm{mg} / \mathrm{kg}$ and sodium valproate. This indicates that EEATR has antiepileptic activity equal to that of sodium valproate in MES model and PTZ model. The antiepileptic activity of EEATR could be due to facilitating the GABAergic inhibitory system (MES model) or calcium channel blockade (PTZ model).

Phytochemical compounds present in Azima tetracantha root are alkaloids, flavonoids, terpenoids, sterols and glycosides. It has been reported that alkaloids [26], flavonoids [27], saponins [28], and terpenoids [29] have antiepileptic activity. It is reported that flavonoids modulate GABA receptors, may reduce the glutamatergic transmission and having a neuroprotective effect [30].

The antiepileptic activity of Azima tetracantha root proven in this study could be due to the presence of these phytochemicals. A similar study conducted by Karunakar Hegde et al. by using root part of Carissa carandas Linn reported that the antiepileptic activity of the plant root could be due to the presence of phytochemicals especially triterpenic steroids and triterpenoidal saponins against MES and PTZ models and alkaloids, monoterpenes, flavonoids against PTZ induced convulsions [31].

Rajasree et al. did the similar study by root extract of Moringa oleifera in which they estimated the biogenic amines such as noradrenaline, serotonin and dopamine in the brain. They observed that there was an increase in these amines in the forebrain region [32]. It is reported that low level of dopamine has an inhibitory effect on glutamate and increase in the same can inhibit the seizure activity [33].

Oxidative stress has been implicated as a cause for epilepsy. Menon $B$ in her study showed that antioxidant status was low in untreated epileptic individuals and not improved with antiepileptic treatment with classical drugs [34]. Most of the plant products evaluated for antiepileptic activity are reported to have antioxidant activity due to their phytochemical content. The in vitro antioxidant activity of Azima tetracantha root extract and in vivo activity of kidney tissue has been reported by konda et al. 2015[19]. Hence it can be inferred that the antiepileptic activity of EEATR could be not only due to its effect GABAergic transmission and calcium channel blockade but also could be due to antioxidant activity.

Further studies are required to find an exact mechanism and exact chemical compound responsible for its antiepileptic activity using genetic models which closely resemble idiopathic epilepsy in humans. 


\section{CONCLUSION}

The present study on Azima tetracantha root extract has shown that it has anticonvulsant activity in both MES and PTZ induced seizure in mice. EEATR in the dose of 250 and $500 \mathrm{mg} / \mathrm{kg}$ was found to be safe and effective in preventing seizures in both the models. In MES model 250 and $500 \mathrm{mg} / \mathrm{kg}$ of EEATR effectively decreased the duration of tonic hind limb extension. The anticonvulsant activity was significant with $500 \mathrm{mg} / \mathrm{kg}$ of EEATR compared to control. In PTZ model EEATR $500 \mathrm{mg} / \mathrm{kg}$ protected $50 \%$ of animals from death which was comparable to sodium valproate. The antiepileptic activity of Azima tetracantha root extract could be due to its phytochemical compounds. The probable mechanism could be due to the modulatory effect on central neurotransmitter system as well as antioxidant activity. Further studies are required to explore its mechanism of action and the active principle responsible for its action. These findings can be taken forward to develop new antiepileptic drug with less side effects.

\section{ACKNOWLEDGEMENT}

I would like to thank Dr. Sobita devi, Veterinary surgeon for providing animals and Mr. Vijayvel, Animal house lab technician for his support during work.

\section{CONFLICT OF INTERESTS}

Declare none

\section{REFERENCES}

1. Panayiotopoulos CP. Clinical aspects of the diagnosis of epileptic seizures and epileptic syndromes. The Epilepsies: Seizures, Syndromes and Management. In: Panayiotopoulos CP. Editor. Oxfordshire (UK): Bladon Medical Publishing; 2005. p. 1

2. World Health Organization. Epilepsy, Fact sheet No.999 October 2012. Available from: www.who.int/media centre/factsheets/ fs999/en. [Last accessed on 20 Jun 2016].

3. Hesdorffer DC, Logroscino G, Benn EK, Katri N, Cascino G, Hauser WA. Estimating risk for developing epilepsy: a population-based study in Rochester, Minnesota. Neurology 2011;76:23-7.

4. Hauser WA, Annegers JF, Kurland LT. The incidence of epilepsy and unprovoked seizures in Rochester, Minnesota: 1935-1984. Epilepsia 1993;34:453-68.

5. Lindsten H, Nystrom L, Forsgren L. Mortality risk in an adult cohort with a newly diagnosed unprovoked epileptic seizure: a population-based study. Epilepsia 2000;41:1469-73.

6. Christensen J, Vestergaard $M$, Mortensen $\mathrm{PB}$, Sidenius $\mathrm{P}$, Agerbo E. Epilepsy and risk of suicide: a population-based casecontrol study. Lancet Neurol 2007;6:693-8.

7. Heaney DC, MacDonald BK, Everitt A, Stevenson S, Leonardi GS, Wilkinson P, et al. Socioeconomic variation in the incidence of epilepsy: prospective community-based study in south-east England. Br Med J 2002;325:1013-6.

8. Hesdorffer DC, Tian H, Anand K, Hauser WA, Ludvigsson P, Olafsson E, et al. Socioeconomic status is a risk factor for epilepsy in Icelandic adults but not in children. Epilepsia 2005;46:1297-303.

9. Bialer M, Johannessen SI, Levy RH, Perucca E, Tomson T, White HS. Progress report on new antiepileptic drugs: a summary of the Ninth Eilat Conference (EILAT IX). Epilepsy Res 2009;83:1-43.

10. Temkin NR. Antiepileptogenesis and seizure prevention trials with antiepileptic drugs: a meta-analysis of controlled trials. Epilepsia 2001;42:515-24.

11. Bloch KM, Sills GJ, Pirmohamed M, Alfirevic A. Pharmacogenetics of antiepileptic drug-induced hypersensitivity. Pharmacogenomics 2014;15:857-68.

12. Hasan S, Dwivedi V, Misra M, Prashant KS, Hashmi F, Ahmed T. Antiepileptic activity of some medicinal plants. Int J Med Aromat Plants 2012;2:354-60.

13. Malvi Reetesh K, Bigoniya Papiya, Sethi sunny, Jain Sonam. Medicinal plants used in the treatment of epilepsy. Int Res J Pharm 2011;2:32-9.

14. Lucindo J Quintans Júnior, Jackson RGS Almeida, Julianeli T Lima. Plants with anticonvulsant properties-a review. Brazilian J Pharmacogn 2008;18(Suppl):798-819.
15. P Dold. Azima tetracantha Lam. In: GH Schmelzer, A Grurib Fakim. editors. Plant resources of tropical Africa 11, Medicinal plants. Vol. 1. PROTA foundation, Wageningen, Netherlands, Backhuys publishers/CTA; 2008. p. 109.

16. Hepsibha BT, Sathiya S, SaravanaBabu C, Premalakshmi V, Sekar T. In vitro studies on antioxidant and free radical scavenging activities of Azima tetracantha. Lam leaf extracts. Indian J Sci Technol 2010;3:571-7.

17. Antonisamy P, Duraipandiyan V, Ignacimuthu S. Antiinflammatory, analgesic and antipyretic effects of friedelin isolated from Azima tetracantha Lam. in mouse and rat models. J Pharm Pharmacol 2011;63:1070-7.

18. Muthusamy P, Jerad Suresh A, Balamurugan G. Antiulcer activity of azima tetracantha. A biochemical study. Res J Pharm Technol 2009;2:344-8.

19. Konda VR, Arunachalam R, Eerike M, Rao R, Radhakrishnan AK, Raghuraman L P, et al. Nephroprotective effect of ethanolic extract of Azima tetracantha root in glycerol-induced acute renal failure in Wistar albino rats. J Traditional Complementary Med 2015;1-8. [Article in Press]

20. Bennett R, Mellon F, Rosa E, Perkins L, Kroon P. Profiling glucosinolates, flavonoids, alkaloids, and other secondary metabolites in tissues of Azima tetra-cantha L. (Salvadoraceae). J Agric Food Chem 2004;52:5856-62.

21. Gayathri G, Nair Bindu R, Babu V. GC-MS Analysis of Azima tetracantha. J Pharm Res 2012;5:3746-7.

22. Sundaresan Nandhini, Ramalingam Radha. Pharmacognosy of Azima tetracantha lam: a review. Indian J Adv Plant Res 2015;3:13-9.

23. Schmutz M, Portet $\mathrm{C}$, Jeker A, Klebs K, Vassout A, Allgeier $\mathrm{H}$, et al. The competitive NMDA receptor antagonists CGP 37849 and CGP 39551 are potent, orally-active anticonvulsants in rodents. Naunyn Schmiedebergs Arch Pharmacol 1990;342:61-6.

24. Swinyard EA, Kupferberg HJ. Antiepileptic drugs: detection, quantification, and evaluation. Fed Proc 1985;44:2629-33.

25. Gupta SK. Antiepileptics. Drug screening methods. In: Gupta SK. Editor. Jaypee Brothers medical Publishers (p) Ltd; 2006. p. 92-3.

26. Bhutada P, Mundhada Y, Bansod K, Dixit P, Umathe S, Mundhada D. Anticonvulsant activity of berberine, an isoquinoline alkaloid in mice. Epilepsy Behav 2010;18:207-10.

27. Fernández SP, Wasowski C, Loscalzo LM, Granger RE, Johnston GA, Paladini AC, et al. Central nervous system depressant action of flavonoid glycosides. Eur J Pharmacol 2006;539:168-76.

28. Chindo BA, Anuka JA, McNeil L, Yaro AH, Adamu SS, Amos S, et al. Anticonvulsant properties of saponins from Ficus platyphylla stem bark. Brain Res Bull 2009;78:276-82.

29. Suresh Kumar, Reecha Madaan, Gundeep Bansal, Anupam Jamwal, Anupam Sharma. Plants and plant products with potential anticonvulsant activity-a review. Pharmacogn Commun 2012;2:3-99.

30. Choudhary N, Bijjem KR, Kalia AN. The antiepileptic potential of flavonoids fraction from the leaves of anisomeles malabarica. J Ethnopharmacol 2011;135:238-42.

31. Karunakar Hegde, Shalin P Thakker, Arun B Joshi, CS Shastry, KS Chandrashekhar. Anticonvulsant activity of carissa carandas Linn. root extract in experimental mice. Trop J Pharm Res 2009;8:117-25.

32. Rajasree PH, Ranjith Singh, C Sankar. Screening for the antiepileptic activity of Moringa oleifa root extract. Int J Pharm Life Sci 2012;3:2115-9.

33. Rajesh A Shastry, Smita D Madagundi, Prasanna V Habbu, Basavaraj S Patil, Shrinivas D Joshi, Venkatrao H Kulkarni. Phytochemical investigation and antiepileptic activity of asparagus racemosus (Wild) root extract in rodents. RGUHS J Pharm Sci 2015;5:97-103.

34. Menon B, Ramalingam K, Kumar RV. Low plasma antioxidant status in patients with epilepsy and the role of antiepileptic drugs on oxidative stress. Ann Indian Acad Neurol 2014;17:398-404.

\section{How to cite this article}

- Madhavi Eerike, Venu Gopala Rao Konda, Ruckmani Arunachalam, Umar Dawood. Evaluation of antiepileptic activity of ethanolic extract of Azima tetracantha root in mice Int J Curr Pharm Res 2016;8(4):76-79. 